\title{
Parathyroidectomy is a reliable treatment option for chronic kidney disease patients with secondary hyperthyroidism (SHPT)
}

Changying Xing ( $\sim$ cyxing1962@gmail.com )

Jiangsu Province hospital

Hongqing Cui

Jiangsu Province Hospital and Nanjing Medical University First Affiliated Hospital

Jingjing Wu

Jiangsu Province Hospital and Nanjing Medical University First Affiliated Hospital

\section{Li Zhang}

Jiangsu Province Hospital and Nanjing Medical University First Affiliated Hospital

\section{Chunxia Mao}

Jiangsu Province Hospital and Nanjing Medical University First Affiliated Hospital

\section{Baodi Huang}

Jiangsu Province Hospital and Nanjing Medical University First Affiliated Hospital

\section{Huijuan Mao}

Jiangsu Province Hospital and Nanjing Medical University First Affiliated Hospital

\section{Ningning Wang}

Jiangsu Province Hospital and Nanjing Medical University First Affiliated Hospital

\section{Bo Zhang}

Jiangsu Province Hospital and Nanjing Medical University First Affiliated Hospital

Haibin Ren

Jiangsu Province Hospital and Nanjing Medical University First Affiliated Hospital

\section{Research article}

Keywords: Secondary hyperthyroidism, peritoneal dialysis, chronic kidney disease, parathyroidectomy

Posted Date: July 3rd, 2019

DOI: https://doi.org/10.21203/rs.2.10960/v1

License: (c) (1) This work is licensed under a Creative Commons Attribution 4.0 International License.

Read Full License 


\section{Abstract}

Background: Secondary hyperthyroidism (SHPT) is a common complication in chronic kidney disease patients undergoing peritoneal dialysis. It develops as a result of distortions in the regulation of calcium, phosphorus and parathyroid hormone (PTH). SHPT increases with decreasing kidney function. Factors that affect the levels of calcium, phosphorus, and PTH include diet, residual renal function, peritoneal transport properties, and dialysate calcium concentration. Treatment options for SHPT include pharmaceutical and surgical removal of parathyroid glands. Although there are treatment options for kidney disease patients with SHPT, little improvement has been made in the overall outcome of the patients. Method: Here, we present that parathyroidectomy is a treatment option for patients with SHPT. A test group (peritoneal dialysis patients with SHPT who had surgery plus forearm transplantation) were compared with control group (normal peritoneal dialysis patients without surgery). In both groups, clinical, biochemical and haematological profile assessments were done. Results: The test group after surgery show improved clinical, biochemical and haematological profile comparing with the control (nonsurgery) group. Conclusion: parathyroidectomy (PTX) is a reliable treatment option for patients with SHPT, which brings about improvement in the biochemical, haematological, physiological and clinical parameters as compared with peritoneal dialysis patients with secondary hyperthyroidism without parathyroidectomy plus forearm transplantation.

\section{Background}

Secondary hyperparathyroidism (SHPT) is one of the commonest complications in chronic kidney patients undergoing dialysis. It is involved in skeletal metabolism, cardiovascular and soft-tissue calcification in patients with dialysis. It creates a compounded problem and greatly reduces the quality of life as well as increases the mortality rate of people with chronic kidney disease (1) There are many factors affecting calcium, phosphorus, and parathyroid hormone (PTH) metabolism in maintenance of peritoneal dialysis patients, including diet, residual renal function, peritoneal transport properties, calcium concentration in dialysate and application of phosphorus binders (17). The role of parathyroid hormone involves absorption of calcium from the gut, demineralization of the bones and other connective tissues and absorption and reabsorption of minerals in the kidney during excretion. Secondary hyperparathyroidism develops from the distortions in the regulation of calcium, phosphorus, parathyroid hormone and vitamin D (19).

Parathyroid dysfunction associated with biochemical and bone disorders continues to cause much morbidity including cardiovascular diseases, bone pain and fractures in chronic kidney disease (CKD) patients. $(8,9,10,11,12)$. Uncontrolled SHPT results in up to $20 \%$ of increased mortality $(10,11)$ and a four-fold increase in the incidence of bone fractures due to impaired bone quality in dialysis patients compared with non-dialysis patients $(\mathbf{1 3}, \mathbf{1 4}, \mathbf{1 5})$. Many studies support a global trend in SHPT: $29.48 \%$ among continuous ambulatory peritoneal dialysis (CAPD) patients in Thailand (3), 60\% in Argentina (5) and $47 \%$ in a review studies in Canada (4.) Early diagnosis and reasonable treatment (mainly drug therapy and parathyroidectomy plus forearm transplantation) are important methods to delay such 
complications. Many therapeutic strategies in the management of mineral bone disease in chronic kidney disease (CKD-MBD) patients target the control of SHPT including the use of calcimimetics, vitamin D sterols (18), phosphate binders and surgical procedures $(6,7)$. Pharmacological treatment of SHPT presents with high cost (16), many side effects, non-compliance and several reported cases of resistance to vitamin D analogs. Parathyroidectomy (PTX) is fast becoming the medical treatment of choice among chronic kidney disease patients with secondary hyperparathyroidism despite the contribution of pharmaceutical therapy. PTX brings relief and considerable improvement in the laboratory and clinical well-being of peritoneal dialysis (PD) patients. In a recent article by Eidman and Wetmore, even though parathyroidectomy may be beneficial as a remedy for secondary hyperparathyroidism, they cautioned that care must be taken to monitor clinical symptoms and laboratory values in these patients.

Parathyroidectomy as a common method for the treatment of secondary hyperparathyroidism following chronic kidney diseases, lacks enough clinical and laboratory evidence. This study therefore seeks to bring to bear the clinical, biochemical, haematological and physiological support for parathyroidectomy in people living with chronic kidney disease undergoing peritoneal dialysis.

\section{Methods}

\section{Study subjects}

65 peritoneal dialysis patients from November 2013 to June 2016 in Jiangsu Province Hospital were enrolled. Peripheral plasma was obtained from all enrolled patient. 25 patients eventually get parathyroidectomy plus forearm transplantation surgery due to secondary hyperparathyroidism (surgery group), while another 40 without secondary hyperparathyroidism did not get this surgery (non-surgery group). Moreover, the 25 patients were followed up to $72 \mathrm{~h}$ after surgery. The writing consents were obtained from each patient, and this study was approved by the Ethics Committee of Jiangsu Province Hospital.

\section{Observed parameters}

Age, height, gender, liver function parameters (ALT, AST and ALP), hematological profiles (Hb, RBC, WBC, PLT, HCT and blood iron), total protein, albumin, globulin, triglycerides, cholesterol, HDL and LDL, phosphate calcium, kidney function parameters (urea creatinine and uric acid) are compared between surgery and non-surgery group.

\section{Statistical analysis}

SPSS 19.0 software package was used to analyze the data from this study. T test was used to compare the quantitative data between two groups. To examine the qualitative data between surgery and nonsurgery group, the Chi-square test was used. A two-tailed probability less than 0.05 was inferred as statistically significant.

\section{Results}


Comparison on clinical parameters between surgery and without surgery groups. We analyzed if the groups will have a significant impact on the clinical parameters of the patients. The mean age for the surgery group was 44.80 years as compared to the non-surgery group which was 46.45 years $(P=0.67)$ (Sup. Table 1). There was no significant height difference between the surgery group $(162.60 \mathrm{~cm})$ and non-surgery group $(164.17 \mathrm{~cm})(p=0.58)$ (Sup. Table 1$)$. The mean difference between the two groups with respect to weight $(p=0.72)$ and gender $(p=0.47)$ was not significant (Sup. Table 1$)$. The liver function parameters (ALT, AST and ALP) between the surgery and non-surgery groups were highly significant $(p=0.001)$ with levels lower in surgery groups compared to non-surgery groups with the exception of ALP (557.72 vs 130.79) (Table 1). There was also no significant difference between the groups with regards to hematological profiles (Hb, RBC, WBC, PLT, HCT and blood iron) (Table 1). Significant difference was observed in the mean values for total protein $(p=0.001)$, albumin $(p=0.001)$ and globulin $(p=0.03)$ between the surgery and non-surgery groups (Table 1$)$. The mean values of triglycerides $(p=0.91)$, cholesterol $(p=0.34), H D L(p=0.10)$ and LDL ( $p=0.73)$ were not significantly differently between both groups (Table 1). Patients in the surgery group had a lower mean phosphate $(2.23 \mathrm{mmol} / \mathrm{L})$ compared to the non-surgery group $(1.68 \mathrm{mmol} / \mathrm{L})(p=0.001)$ (Table 1$)$. The mean levels of calcium between the groups were not different. Kidney function parameters were not different between both groups as demonstrated by the mean values of urea $(p=0.17)$, creatinine $(p=0.56)$ and uric acid $(p=0.48)$ (Table 1). Dialysis method and composition affects the overall performance of SHPT patients after surgery.The method of dialysis plays a key role in the SHPT patients' responses. In Table 2, there is a significant correlation between continuous ambulatory peritoneal dialysis (CAPD) and daytime ambulatory peritoneal dialysis (DAPD) $(p=0.01)$ in both pre-surgery and surgery groups. The volume of dialysis had no significant correlation between patients in both groups $(p=0.47)$ irrespective of the amount, $6 \mathrm{~L}, 8 \mathrm{~L}, 10 \mathrm{~L}$ or $12 \mathrm{~L}$ (Table 3 ). The glucose composition $(1.5 \%, 1.5 \%+2.5 \%$ mix or $2.5 \%)$ of the dialysis fluid however, showed a significant correlation between the patients in the surgery and pre-surgery groups $(p=0.01)$ (Table 3). Parathyroidectomy reduces PTH levels in a time-dependent manner whereas calcium levels improve with time.SHPT patients report with increased levels of PTH and hypocalcaemia. Improving these clinical parameters is crucial to the survival of the patients. Parathyroidectomy reduced blood PTH levels from a mean value of $1,591.86 \mathrm{pg} / \mathrm{ml}$ to $63.45 \mathrm{pg} / \mathrm{ml}$ within 24 hours. PTH levels were further reduced on day 3 (72 hours) post-surgery to $39.44 \mathrm{pg} / \mathrm{ml}(\mathrm{p}=0.0001)$ (Table 4). Mean calcium level in the pre-operative group was $2.39 \mathrm{mmol} / \mathrm{L}$; however, $24 \mathrm{~h}$ post-surgery, mean calcium level further reduced to $1.94 \mathrm{mmol} / \mathrm{L}$. The level started rising after day 3 post-surgery to $2.15 \mathrm{mmol} / \mathrm{L}(\mathrm{p}=0.0001)$ (Table 5). Moreover, we did the comparison on mean calcium and PTH levels (pre-surgery and post-surgery) among different groups of patients receiving parathyroidectomy. We firm confirm that parathyroidectomy reduces PTH levels after $24 \mathrm{~h}(\mathrm{p}<0.05)$ and $72 \mathrm{~h}(\mathrm{p}<0.05)$. Whereas calcium levels reduce to $1.94 \mathrm{mmol} / \mathrm{L}$ at $24 \mathrm{~h}$ after parathyroidectomy but increase to $2.15 \mathrm{mmol} / \mathrm{L}$ at $72 \mathrm{~h}$ after surgery and the difference is significant (Table 6).

\section{Discussion}


SHPT is a common complication among people with chronic kidney disease undergoing some form of maintenance dialysis (including peritoneal dialysis). SHPT heightens as kidney function declines. Secondary hyperparathyroidism presents with laboratory and clinical modifications in the physiological parameters of the body. The treatment of SHPT involves both pharmaceutical and surgical methods. Some studies show that high cost of drugs, side effects, resistance to some drugs is increasing the choice of surgical treatment for SHPT. This study sought to establish the impact of parathyroidectomy with or without forearm transplantation on clinical, physiologic and laboratory parameters.

The study is a comparative study that compares test group (peritoneal dialysis patients with SHPT who had surgery done as a treatment method) with a control group (normal peritoneal dialysis patients with no secondary hyperthyroidism and for that matter had no surgery). Data was collected at two levels of the study (the preoperative and postoperative data). At the preoperative level, basic information was collected on both participants in the surgery and non-surgery groups. At the postoperative level, data was collected on only surgery group participants. After parathyroidectomy, chronic kidney disease patients with SHPT experience a decrease in the levels of PTH after 24 hours. The levels of PTH even decreased further to $39.44 \mathrm{pg} / \mathrm{mL}$ after 72 hours. This suggestive those peritoneal dialysis patients with SHPT who undergo surgery see PTH improvement in a time-dependent manner. Although PTH levels decrease after 24 hours, calcium levels which are expected to rise in a time dependent manner doesn't. It decreases at 24 hours post-surgery but gradually increases after 72 hours post-surgery. The glucose composition of the dialysis fluid also plays a key role in the overall outcome of SHPT patients. There was a significant difference between the glucose composition used in the dialysis process $(p=0.01)$ but not the volume of dialysis fluid $(p=0.47)$. This information will provide clinicians the better option when considering the optimal dialysis method to improve patient care while reducing PTH levels and improving calcium levels.

From the results gathered during the study, we have demonstrated that parathyroidectomy is a treatment alternative for the management of secondary hyperthyroidism among peritoneal dialysis patients. It brings about improvement in the biochemical, haematological, physiological and clinical parameters as compared with peritoneal dialysis patients with secondary hyperthyroidism without parathyroidectomy plus forearm transplantation. The study however is limited by the small sample size and one dialysis centre bias. We suggest therefore similar study be repeated in a large sample size cross sectional multicentre dialysis points to eliminate biases.

In conclusion, our study indicates that PTX is a reliable treatment option for patients with SHPT, which brings about improvement in the biochemical, haematological, physiological and clinical parameters as compared with peritoneal dialysis patients with secondary hyperthyroidism without parathyroidectomy plus forearm transplantation.

\section{Declarations}

Ethics approval and consent to participate 
The writing consents were obtained from each patient, and this study was approved by the Ethics Committee of Jiangsu Province Hospital.

\section{Consent for publication}

Written consent was provide by patients involving in this study and a copy of the written consent is available for review by the Editor-in-Chief of this journal.

\section{Availability of data and material}

This article is distributed under the terms of the Creative Commons Attribution 4.0 International License (http://creativecommons.org/licenses/by/4.0/), which permits unrestricted use, distribution, and reproduction in any medium, provided you give appropriate credit to the original author(s) and the source, provide a link to the Creative Commons license, and indicate if changes were made. The Creative Commons Public Domain Dedication waiver (http://creativecommons.org/publicdomain/zero/1.0/) applies to the data made available in this article, unless otherwise stated.

\section{Competing interests}

All the authors declare there is no conflict of interest.

\section{Funding}

This report was not supported by any funding.

\section{Authors' contributions}

Research design: Hongqing Cui, Jingjing Wu ; Conducted experiments: Hongqing Cui,Li Zhang, Chunxia Mao. Contributed analytic tools: Baodi Huang. Data analysis: Huijuan Mao, Ningning Wang. Manuscript writing: Haibin Ren, Changying Xing. All authors read and approved the final manuscript.

Acknowledgements

None.

\section{References}

1. Slatopolsky E, Delmez J: Pathogenesis of secondary hyperparathyroidism. Am J Kidney Dis 1994;23: 229-236.

2. Eidman, Keith E, Wetmore, James B: The role of Hyperparathyroidectomy in the management of secondary hyperparathyroidism. Current opinions in Nephrology and hypertension 2017; 26(6): $p$ 516-22. From Doi:https://doi.org/10/1097

3. Suman N Sept 2011, Secondary hyperthyroidism and risk factors in patients undergoing peritoneal dialysis in a tertiary hospital. J Med Assoc Thai, 94 suppl 4: s101-5 
4. Billa V, Zhong A, Bargman J, Vas S, Wong PY, Oreopoulos DG. Perit Dial Int May-Jun 2000 ;20(3): A review of 176 patients

5. Douthat WG, Castellano M, Berenguer L, Guzman MA, de Arteaga J, Chiurchiu CR, Massari PU, Garay G, Capra R, de La Fuente JL: High prevalence of SPTH in Chronic kidney disease patients on dialysis in Argentina. Nefrologia 2013 33(5): 657-66

6. Block GA, Martin KJ, de Francisco AL, Turner SA, Avram MM, Suranyi MG, et al. Cinacalcet for secondary hyperparathyroidism in patients receiving hemodialysis. N Engl J Med 2004; 350:1516-25.

7. Strippoli GF, Palmer S, Tong A, Elder G, Messa P, Craig JC. Meta-analysis of biochemical and patientlevel effects of calcimimetic therapy. Am J Kidney Dis 2006;47: 715-26.

8. Streja E, Wang HY, Lau WL, Molnar MZ, Kovesdy CP, Kalantar-Zadeh K, et al. Mortality of combined serum phosphorus and parathyroid hormone concentrations and their changes over time in hemodialysis patients. Bone. 2014;61:201-7.

9. Block GA, Hulbert-Shearon TE, Levin NW, Port FK. Association of serum phosphorus and calcium $x$ phosphate product with mortality risk in chronic hemodialysis patients: a national study. Am J Kidney Dis. 1998;31(4):607-17.

10. Block GA, Klassen PS, Lazarus JM, Ofsthun N, Lowrie EG, Chertow GM. Mineral metabolism, mortality, and morbidity in maintenance hemodialysis. J Am Soc Nephrol. 2004;15(8):2208-18.

11. Tentori F, Blayney MJ, Albert JM, Gillespie BW, Kerr PG, Bommer J, et al. Mortality risk for dialysis patients with different levels of serum calcium, phosphorus, and PTH: the Dialysis Outcomes and Practice Patterns Study (DOPPS). Am J Kidney Dis. 2008;52(3):519-30.

12. Young EW, Albert JM, Satayathum S, Goodkin DA, Pisoni RL, Akiba T, et al. Predictors and consequences of altered mineral metabolism: the Dialysis Outcomes and Practice Patterns Study. Kidney Int. 2005;67(3):1179-87.

13. Maravic M, Ostertag A, Torres PU, Cohen-Solal M. Incidence and risk factors for hip fractures in dialysis patients. Osteoporos Int. 2014;25(1):159-65.

14. Negri AL, Del Valle EE, Zanchetta MB, Nobaru M, Silveira F, Puddu M, et al. Evaluation of bone microarchitecture by high-resolution peripheral quantitative computed tomography (HR-pQCT) in hemodialysis patients. Osteoporos Int. 2012;23(10):2543-50.

15. Nickolas TL, Stein EM, Dworakowski E, Nishiyama KK, Komandah-Kosseh M, Zhang CA, et al. Rapid cortical bone loss in patients with chronic kidney disease. Journal of bone and mineral research : The official journal of the American Society for Bone and Mineral Research. 2013;28(8):1811-20.

16. Garside R, Pitt M, Anderson R, Mealing S, Roome C, Snaith A, D'Souza R, Welch K, Stein K: The effectiveness and cost-effectiveness of cinacalcet for secondary hyperthyroidism in end-stage renal diseases patients on dialysis: A systematic review and economic evaluation. Health Technol 2007. 11(18): 1-167

17. Levin, A., Bakris, G.L., Molitch, M., Smulders, M.; Tian, J., Williams, L.A., Andress, D.L. Prevalence of abnormal serum vitamin D, PTH, calcium and phosphorus in patients with chronic kidney disease: Results of the study to evaluate early kidney disease. Kidney Int. 2007, 71, 31-38. 
18. Christakos, S.; Dhawan, P.; Verstuyf, A.; Verlinden, L.; Carmeliet, G. Vitamin D: Metabolism, Molecular Mechanism of Action, and Pleiotropic Effects. Physiol. Rev. 2016, 96, 365-408.

19. Block GA, Port FK: Re-evaluation of risks associated with hyperphosphataemia and hyperparathyroidism in dialysis patients: Reccommendation for a change in management. Am J Kidney Dis 2000. 35:1226-1237

\section{Tables}

Table 1: Partial comparison of quantitative data from surgical and nonsurgical groups with (paired $T$ test) 


\begin{tabular}{|c|c|c|c|c|c|c|c|}
\hline Objects & $\begin{array}{c}1=\text { surgical } \\
\text { group } \\
2=\text { nonsurgical } \\
\text { group }\end{array}$ & Number & average & $\begin{array}{l}\text { Standard } \\
\text { error }\end{array}$ & $\begin{array}{c}\mathrm{T} \\
\text { value }\end{array}$ & $\mathrm{df}$ & $\begin{array}{c}\text { Sig.( } \\
\text { Bilateral) }\end{array}$ \\
\hline Albumin & 1 & 25 & 31.70 & 3.14 & & & \\
\hline $\mathrm{g} / \mathrm{L}$ & 2 & 40 & 36.11 & 5.26 & -4.24 & 62.91 & 0.00 \\
\hline cholesterol & 1 & 25 & 4.41 & 1.18 & & & \\
\hline $\mathrm{mmol} / \mathrm{L}$ & 2 & 40 & 4.71 & 1.23 & -0.95 & 52.61 & 0.34 \\
\hline Triglyceride & 1 & 25 & 1.64 & 0.78 & & & \\
\hline $\mathrm{mmol} / \mathrm{L}$ & 2 & 40 & 1.61 & 0.86 & 0.11 & 55.13 & 0.91 \\
\hline Urea & 1 & 25 & 21.46 & 5.38 & & & \\
\hline$(\mathrm{mmol} / \mathrm{l})$ & 2 & 40 & 19.52 & 5.75 & 1.38 & 53.68 & 0.17 \\
\hline Creatinine & 1 & 25 & 1025.45 & 235.65 & & & \\
\hline$(\mu \mathrm{mol} / \mathrm{L})$ & 2 & 40 & 1065.34 & 307.06 & -0.59 & 60.23 & 0.56 \\
\hline Uric acid & 1 & 25 & 427.00 & 74.21 & & & \\
\hline \multirow[t]{2}{*}{$(\mu \mathrm{mol} / \mathrm{L})$} & 2 & 40 & 411.51 & 101.44 & 0.71 & 61.32 & 0.48 \\
\hline & 1 & 13 & 10.42 & 4.60 & & & \\
\hline $\mathrm{ALT}(\mathrm{U} / \mathrm{L})$ & 2 & 38 & 16.09 & 7.06 & -3.31 & 32.30 & 0.00 \\
\hline \multirow[t]{2}{*}{$\operatorname{AST}(\mathrm{U} / \mathrm{L})$} & 1 & 12 & 12.51 & 4.11 & & & \\
\hline & 2 & 38 & 20.96 & 7.42 & -5.00 & 34.49 & 0.00 \\
\hline \multirow[t]{2}{*}{ High-density lipoprotein mg/L } & 1 & 25 & 1.01 & 0.26 & & & \\
\hline & 2 & 34 & 1.13 & 0.29 & -1.70 & 54.71 & 0.10 \\
\hline \multirow[t]{2}{*}{ Low-density lipoprotein mg/L } & 1 & 25 & 2.99 & 0.79 & & & \\
\hline & 2 & 34 & 3.08 & 1.06 & -0.35 & 56.98 & 0.73 \\
\hline \multirow[t]{2}{*}{$\mathrm{Ca}(\mathrm{mmol} / \mathrm{L})$} & 1 & 25 & 2.39 & 0.24 & & & \\
\hline & 2 & 40 & 2.39 & 0.32 & -0.06 & 60.64 & 0.96 \\
\hline \multirow[t]{2}{*}{$\mathrm{P}(\mathrm{mmol} / \mathrm{L})$} & 1 & 25 & 2.23 & 0.53 & & & \\
\hline & 2 & 40 & 1.68 & 0.50 & 4.09 & 48.78 & 0.00 \\
\hline \multirow[t]{2}{*}{$\mathrm{K}(\mathrm{mmol} / \mathrm{L})$} & 1 & 25 & 3.73 & 0.64 & & & \\
\hline & 2 & 40 & 4.10 & 0.77 & -2.13 & 57.96 & 0.04 \\
\hline \multirow[t]{2}{*}{$\mathrm{Na}(\mathrm{mmol} / \mathrm{L})$} & 1 & 12 & 140.29 & 3.43 & & & \\
\hline & 2 & 40 & 139.28 & 3.09 & 0.92 & 16.74 & 0.37 \\
\hline \multirow[t]{2}{*}{$\mathrm{Cl}(\mathrm{mmol} / \mathrm{L})$} & 1 & 12 & 97.68 & 3.19 & & & \\
\hline & 2 & 40 & 97.28 & 3.11 & 0.38 & 17.75 & 0.71 \\
\hline \multirow[t]{2}{*}{$\mathrm{Mg}(\mathrm{mmol} / \mathrm{L})$} & 1 & 11 & 0.98 & 0.16 & & & \\
\hline & 2 & 39 & 0.98 & 0.19 & 0.02 & 18.12 & 0.99 \\
\hline \multirow[t]{2}{*}{$\mathrm{CRP}(\mathrm{mg} / \mathrm{L})$} & 1 & 20 & 9.77 & 17.59 & & & \\
\hline & 2 & 32 & 14.80 & 26.55 & -0.82 & 49.78 & 0.42 \\
\hline \multirow[t]{2}{*}{$\mathrm{LDH}$} & 1 & 12 & 218.25 & 54.79 & & & \\
\hline & 2 & 34 & 236.71 & 77.17 & -0.89 & 27.33 & 0.38 \\
\hline Ferritin & 1 & 22 & 403.63 & 477.83 & & & \\
\hline $\mathrm{g} / \mathrm{L}$ & 2 & 32 & 314.97 & 286.77 & 0.78 & 31.38 & 0.44 \\
\hline \multirow[t]{2}{*}{ Transferrin saturation (\%) } & 1 & 20 & 27.30 & 16.15 & & & \\
\hline & 2 & 32 & 32.47 & 13.54 & -1.19 & 35.18 & 0.24 \\
\hline \multirow[t]{2}{*}{ Alkaline phosphatase } & 1 & 25 & 557.72 & 548.59 & & & \\
\hline & 2 & 34 & 130.79 & 120.68 & 3.82 & 25.71 & 0.00 \\
\hline Hemoglobin & 1 & 25 & 92.04 & 18.51 & & & \\
\hline $\mathrm{G} / \mathrm{L}$ & 2 & 40 & 97.31 & 20.80 & -1.06 & 55.54 & 0.29 \\
\hline
\end{tabular}




\begin{tabular}{|c|c|c|c|c|c|c|c|}
\hline Hct & 1 & 12 & 0.29 & 0.05 & & & \\
\hline$\%$ & 2 & 40 & 0.30 & 0.06 & -0.15 & 21.60 & 0.89 \\
\hline Plt & 1 & 12 & 205.25 & 75.53 & & & \\
\hline $10^{\wedge} 9 / \mathrm{L}$ & 2 & 40 & 200.83 & 79.27 & 0.18 & 18.89 & 0.86 \\
\hline \multirow[t]{2}{*}{$\mathrm{PTH} \square \mathrm{pg} / \mathrm{ml} \square$} & 1 & 25 & 289.35 & 217.36 & & & \\
\hline & 2 & 40 & 1609.80 & 508.71 & 12.30 & 29.55 & 0.00 \\
\hline 25-hydroxy-vitamin D (blood & 1 & 25 & 14.52 & 9.15 & & & \\
\hline level) $(\mathrm{nmol} / \mathrm{L})$ & 2 & 30 & 16.87 & 11.76 & -0.83 & 52.78 & 0.41 \\
\hline $\mathrm{RBC}$ & 1 & 12 & 3.54 & 1.31 & & & \\
\hline$\left(10^{\wedge} 12 / \mathrm{L}\right)$ & 2 & 38 & 3.23 & 0.69 & 0.79 & 13.00 & 0.45 \\
\hline WBC & 1 & 12 & 5.76 & 2.18 & & & \\
\hline$\left(10^{\wedge} 9 / \mathrm{L}\right)$ & 2 & 38 & 6.80 & 1.92 & -1.48 & 16.75 & 0.16 \\
\hline$\beta$-2microglobulin & 1 & 9 & 38.42 & 9.38 & & & \\
\hline$\%$ & 2 & 13 & 45.80 & 11.71 & -1.64 & 19.47 & 0.12 \\
\hline Folic acid & 1 & 4 & 33.39 & 25.37 & & & \\
\hline $\mathrm{nmol} / \mathrm{L}$ & 2 & 26 & 30.45 & 18.32 & 0.22 & 3.50 & 0.84 \\
\hline
\end{tabular}

Table 2: Comparison among different dialysis method (CAPD and DAPD) (Chi-square test of counting data, Fisher's exact method).

\begin{tabular}{lllll}
\hline Dialysis method & & Chi-square value & Pvalue \\
& Surgical group(number) & Nonsurgical group(number) & & \\
\hline CAPD & 13 & 26 & 13.63 & 0.001 \\
DAPD & 12 & 5 & & \\
\hline
\end{tabular}

Table 3: Comparison among different dialysis volumen6L, 8L, 10L, 12L) and glucose concentration of dialysis fluidn1.5\%, $1.5 \%+2.5 \%$ mix]2.5 \%) (Chi-square test of counting data, Fisher's exact method)

\begin{tabular}{|l|l|l|l|l|}
\hline \multirow{2}{*}{ Dialysisvolume } & group & Chi-square value & Pvalue \\
\cline { 2 - 3 } & surgical group(number) & Nonsurgical group(number) & & \\
\hline $6 \mathrm{~L}$ & 2 & 4 & 2.31 & \\
\hline $8 \mathrm{~L}$ & 20 & 22 & & \\
\hline $10 \mathrm{~L}$ & 2 & 5 & & \\
\hline $12 \mathrm{~L}$ & 1 & 0 & \multirow{2}{*}{10.20} & \\
\hline $1.5 \%$ & 4 & 11 & & \\
\hline $1.5 \%+2.5 \%(\mathrm{mix})$ & 15 & 16 & & \\
\hline $2.5 \%$ & 6 & 4 & & \\
\hline
\end{tabular}

Table 4: Comparison between mean PTH levels amongst pre-surgery and post-surgery groups. 


\begin{tabular}{|l|l|l|l|l|l|}
\hline & Average & $\begin{array}{l}\text { Standard } \\
\text { error }\end{array}$ & number & Fisher'svalue & $\begin{array}{l}\text { P } \\
\text { value }\end{array}$ \\
\cline { 1 - 4 } PTH level(Pre-surgery) & 1591.86 & 554.14 & 19 & 160.50 & .000 \\
\cline { 1 - 4 } $\begin{array}{l}\text { PTH level of non-transplantation side(24h after } \\
\text { surgery) }\end{array}$ & 63.45 & 74.90 & 19 & & \\
\cline { 1 - 4 } $\begin{array}{l}\text { PTH level of non-transplantation side (72h after } \\
\text { surgery) }\end{array}$ & 39.44 & 87.79 & 19 & & \\
\hline
\end{tabular}

Table 5: Comparison between mean calcium levels among pre-surgery and post-surgery groups

\begin{tabular}{|l|l|l|l|l|l|}
\hline & Averagevalue & Standard error & number & Fisher's value & P value \\
\hline $\mathrm{Ca}^{2+}$ level(Pre-surgery) & 2.39 & 0.24 & 25 & 7329.62 & .000 \\
\cline { 1 - 3 } $\mathrm{Ca}^{2+}$ level(24 h after surgery) & 1.94 & 0.16 & 25 & & \\
\cline { 1 - 3 } $\mathrm{Ca}^{2+}$ level (72h after surgery) & 2.15 & 0.21 & 25 & & \\
\hline
\end{tabular}

Table 6: Comparison between mean calcium and PTH levels amongst pre-surgery and post-surgery groups: Analysis of variance of repeated measures of paired data.

\begin{tabular}{|c|c|c|c|c|c|c|}
\hline \multicolumn{2}{|c|}{ Comparison between each other } & \multirow{3}{*}{$\begin{array}{l}\text { Averagevalue } \\
1602.49 \\
74.34\end{array}$} & \multirow{2}{*}{$\begin{array}{l}\begin{array}{l}\text { Standard } \\
\text { error }\end{array} \\
518.31 \\
\end{array}$} & \multirow{2}{*}{$\begin{array}{l}\text { number } \\
24 \\
\end{array}$} & \multirow{3}{*}{$\begin{array}{l}\mathrm{T} \\
\text { value } \\
14.57\end{array}$} & \multirow{3}{*}{$\begin{array}{l}\begin{array}{l}P \\
\text { value }\end{array} \\
0.00\end{array}$} \\
\hline \multirow{2}{*}{$\begin{array}{l}\text { Pair } \\
1\end{array}$} & PTH level(Pre-surgery) & & & & & \\
\hline & $\begin{array}{l}\text { PTH level of non-transplantation side (24h } \\
\text { after surgery) }\end{array}$ & & 120.72 & 24 & & \\
\hline \multirow{2}{*}{$\begin{array}{l}\text { Pair } \\
2\end{array}$} & PTH level(Pre-surgery) & 1591.86 & 554.14 & 19 & \multirow[t]{2}{*}{12.47} & \multirow[t]{2}{*}{0.00} \\
\hline & $\begin{array}{l}\text { PTH level of non-transplantation side ( } 72 \mathrm{~h} \\
\text { after surgery) }\end{array}$ & 39.44 & 87.79 & 19 & & \\
\hline \multirow{2}{*}{$\begin{array}{l}\text { Pair } \\
3\end{array}$} & $\mathrm{Ca}^{2+}$ level(Pre-surgery) & 2.39 & 0.24 & 25 & \multirow[t]{2}{*}{8.29} & \multirow[t]{2}{*}{0.00} \\
\hline & $\mathrm{Ca}^{2+}$ level(24 h after surgery) & 1.94 & 0.16 & 25 & & \\
\hline \multirow{2}{*}{$\begin{array}{l}\text { Pair } \\
4\end{array}$} & $\mathrm{Ca}^{2+}$ level(Pre-surgery) & 2.39 & 0.24 & 25 & \multirow[t]{2}{*}{3.66} & \multirow[t]{2}{*}{0.00} \\
\hline & $\mathrm{Ca}^{2+}$ level(72 $\mathrm{h}$ after surgery) & 2.15 & 0.21 & 25 & & \\
\hline \multirow[t]{2}{*}{$\begin{array}{l}\text { Pair } \\
5\end{array}$} & $\begin{array}{l}\text { PTH level of non-transplantation (24h after } \\
\text { surgery) }\end{array}$ & 63.45 & 74.90 & 19 & \multirow[t]{2}{*}{1.03} & \multirow[t]{2}{*}{0.32} \\
\hline & $\begin{array}{l}\text { PTH level of non-transplantation (72h after } \\
\text { surgery) }\end{array}$ & 39.44 & 87.79 & 19 & & \\
\hline \multirow{2}{*}{$\begin{array}{l}\text { Pair } \\
6\end{array}$} & $\mathrm{Ca}^{2+}$ level(24 h after surgery) & 1.94 & 0.16 & 25 & \multirow[t]{2}{*}{-4.08} & \multirow[t]{2}{*}{0.00} \\
\hline & $\mathrm{Ca}^{2+}$ level(72 h after surgery) & 2.15 & 0.21 & 25 & & \\
\hline
\end{tabular}

\section{Supplementary Files}

This is a list of supplementary files associated with this preprint. Click to download. 
- Supplementarymaterial.doc

Page $12 / 12$ 